\title{
EXPLORING INDIRECT ASPECTS IN MOTIVATION AND ACADEMIC ACHIEVEMENT DURING The PANDEMIC
}

\author{
Ade Nurhopipah $^{1)}$, Ida Nuraida ${ }^{2)}$, Jali Suhaman ${ }^{3)}$ \\ 1) University Amikom Purwokerto, Indonesia \\ E-mail: ade_nurhopipah@amikompurwokerto.ac.id \\ 2) UIN Sunan Gunung Djati Bandung, Indonesia \\ E-mail: idanuraida@uinsgd.ac.id \\ 3) University Amikom Purwokerto, Indonesia \\ E-mail:jalisuhaman@gmail.com
}

\begin{abstract}
Online learning methodologies are the most influential factor in educational success. However, it cannot be denied that there are non-technical aspects that indirectly affect students' motivation and academic achievement after the Covid-19 pandemic occurred. This study involves paired $t$-tests, regression tests, and partial $t$-tests to analyze the factors that can indirectly shape student motivation and academic achievement in Indonesia's higher schools. The factors studied were related to economic condition, health, habits, and social interaction. The result shows significant changes in learning motivation, economic and health conditions, student interactions with friends and lecturers, student involvement in student activity units and religious activities, use of social media, and time spent reading. The Grade Point Accumulative (GPA) before the pandemic was influenced by learning motivation. However, during the pandemic, the GPA was not significantly affected by learning motivation. Before the pandemic, family engagement and student involvement in religious activities significantly influence the GPA. Meanwhile, the factors that influence learning motivation during the pandemic are student involvement in social activities, interaction with lecturers, health conditions, and time spent reading.
\end{abstract}

Keywords: GPA; Motivation learning; Regression test; The Covid-19 Pandemic

\section{INTRODUCTION}

The Corona Virus Disease 2019 (COVID-19) outbreak has spread throughout the world and has become a global pandemic. Data from the World Health Organization (WHO) in https://covid19.who.int/ shows that in 26 July 2021, there are more than 194 million people in the world who have been confirmed to have this virus, and 4.1 million more of them have died. Although millions of vaccines have been given, the spread of this virus is still alarming in various aspects of life, including education.

The impact of the pandemic on the learning process is felt at the university level. This is because the risk of death from the virus in adults is greater than death in children. Vigilance with "social distancing" or "physical distance" is carried out to reduce contact and spread in dense communities such as campuses. New perspectives and learning methods emerge to ensure the learning process does not stop due to this pandemic. Online learning is one of the spearheads of implementing learning activities in this pandemic era. Many efforts have been made by the government and educational institutions to ensure online learning can be carried out effectively so that learning objectives are still achieved even though there is no face-toface learning. Emergency response in the form of online learning is used as a security strategy implemented by many campuses worldwide, such as research samples at 25 universities in America (Murphy, 2020). The Chinese government seeks to provide flexible online learning to more than 270 million students. The Chinese Ministry of Education has launched the "Disturbed classroom, uninterrupted learning" initiative to ensure that online learning can have the same quality as face-to-face learning (Zhu \& Liu, 2020).

A qualitative study was conducted in Indonesia to define school response and teacher preparation for distance learning during the pandemic (Arlinwibowo et al, 2020). Literature studies explain various obstacles in online teaching and learning activities. These obstacles include mastery of technology, additional costs, additional parental work, unlimited working hours for teachers, and communication and socialization barriers (Suryaman et al., 2020). There were 213 complaints submitted to Komisi Perlindungan Anak Indonesia (KPAI), dominated by complaints about burdensome learning tasks and excessive 
internet use (Tedja, 2020). Other challenges include in the learning process itself, the limitations of a supportive environment, emotional challenges, maintaining a balanced lifestyle, financial difficulties, lack of social interaction, difficulties in adapting, and difficulty of fulfilling competencies, especially in the field of sciences learning that require practices (Patricia Aguilera-Hermida, 2020),(Mahdy, 2020)

Even though there are so many challenges in this pandemic era, there are also positive aspects of this situation. Social restrictions can increase family time and provide opportunities for organizing, self-development, and new activities. In addition, based on several studies, it turns out that online learning does not always negatively impact students. Rahardjo \& Supratmi Pertiwi (2020) concluded that the correlation between student motivation and learning achievement when learning online is low. This indicates that learning motivation during the pandemic does not significantly affect learning achievement. Gonzalez et al. (2020) analyzed the effects of the pandemic on student selfstudy performance in higher education. This study indicates that there is a significant positive effect between students who lockdown on student performance. Lockdown during the pandemic changes student learning strategies, thereby increasing their efficiency. Jawad \& Shalash (2020) also examines the effect of online learning during the pandemic on student academic achievement. The study results indicate that there are differences in academic achievement that increased in general.

Valverde-Berrocoso at el. (2020) conducted a systematic literature study on research topics, theories, modalities, and methodologies used in online learning. This is certainly due to the methodology in online learning is the most influential factor in teaching and learning success. However, various studies have shown that students' motivation and learning also rely on other non-technical aspects. The success of the learning process involves various factors, both related to the intrinsic and extrinsic conditions of students, teachers, and educational institutions. This success is also believed to be closely related to motivation as a psychological aspect that can determine a person's behavior and direction of activity (Panisoara et al., 2020). Febrianto et al. (2020) revealed that social, economic, and cultural factors are important indicators of the ineffectiveness of online learning in several regions in Indonesia. Muslimin \& Harintama (2020) has analyzed students' challenges and motivation by collecting responses from questionnaires and interviews. The results show that the online learning model requires adequate preparation mentally, physically, and financially.

Based on this analysis, this research involves paired $t$ tests, regression tests, and partial $t$-tests to analyze the factors that can indirectly predict motivation and student achievement index in universities in Indonesia. The factors studied are related to factors of the economic condition (Hendri et al., 2020), health condition (Edraki et al., 2016), habits (Balan et al., 2019), and social interaction (Ariani, 2017). We also observed how these aspects changed before and during the pandemic. In addition, this study also reviews the demographic distribution, availability of devices and networks, and the platforms used in online learning. This research is expected to contribute literature that can be used as a scientific basis for policy-making and learning strategies for educators and managers of educational institutions.

\section{METHODOLOGY}

\section{A. Linear Regression}

Linear regression analysis is a statistical approach to calculating the relationship between variables by making an equation model of the linear relationship between the independent and dependent variables. The linear regression technique aims to find the straight line that best fits the existing data. The equation of the regression model with $\mathrm{k}$ independent variables is shown in Equation (1).

$$
Y=a_{0}+a_{1} X_{1}+a_{2} X_{2}+\ldots+a_{k} X_{k}
$$

Furthermore, the regression significance test was conducted by looking for the value of $F_{\text {stat }}$, which involved the Sum Square $(S S)$ of the regression and the residuals. Suppose $F_{\text {stat }}>F_{\text {critical }}$ then the hypothesis is accepted (Nurhopipah, 2019).

\section{B. Paired t-Test and Partial t-Test}

The $t$-test can be used to compare the difference between two variables. The sample used in this study was the same but underwent different treatment or is called a paired sample. The $t$-test will determine whether the difference between the two means is significant or not as a treatment result. In this case, the treatment is the condition before and during the pandemic. The $t$ value for the paired sample difference test can be calculated by Equation (2). Standard Error $(S E)$ results from the ratio of the Standard Deviation and the amount of data.

$$
t_{\text {stat }}=\frac{X_{1}-I_{2}}{\sqrt{s E^{2} \bar{X}_{1}-S E^{2} \bar{X}_{2}}}
$$

In the regression test, we can also find the value of the partial correlation coefficient with the $t$-test to determine whether a variable has a significant effect or not if other variables are controlled. The correlation itself describes the size of the monotonic relationship between two variables. To perform a partial test, suppose there are two independent variables $X_{1}$ and $X_{2}$, then look for the value of the effect of $X_{1}$ on $Y$ if $X_{2}$ is controlled, and $r_{Y 1.2}$ is the correlation of $Y$ with $X_{1}$ if $X_{2}$ is controlled, then $t_{\text {stat }}$ can be searched with Equation (3).

$$
t_{\text {stat }}=\frac{r_{y 1.2} \sqrt{n-7}}{\sqrt{1-r_{y 1.2}^{2}}}
$$




\section{Data and Variables}

Based on observations from various aspects, it is certain that many aspects can affect online learning indirectly. These are non-technical aspects related to social, economic, health, and habits. In the study, observations were made on several variables related to the conditions and habits of students as follows.

1) Social interaction before and during the pandemic: involvement in student activities unit $\left(X_{1}\right)$, involvement in social activities outside the campus $\left(X_{2}\right)$, involvement in religious activities $\left(X_{2}\right)$, interaction with college friends $\left(X_{4}\right)$, interaction with lecturers $\left(X_{5}\right)$ and family engagement $\left(X_{6}\right)$

2) Economic conditions $\left(X_{7}\right)$ and health conditions $\left(X_{8}\right)$ before and during the pandemic.

3) Habits: activity in social media $\left(X_{9}\right)$ and time spend reading $\left(X_{10}\right)$ before and during the pandemic.

4) Learning achievement: GPA $(Y)$ before and during the pandemic.

5) Motivation level (Z) before and during the pandemic.

This study uses sample data from student participation from thirteen universities in Indonesia. Data were collected by surveying 226 students randomly. The data collection technique used an open questionnaire where the subject filled out an online questionnaire from the link sent. Data related to gender, student status as a worker or, location of residence, availability of device data, network identity, and platforms used by students are also collected as additional information.

\section{Statistical Test Design}

The data obtained through a pre-processing in the form of data transformation and data normalization. Furthermore, a paired $t$-test was carried out for variables before and during the pandemic. Regression tests were also carried out to determine what factors had a significant effect on student achievement and motivation before and during the pandemic. After the regression test, the partial correlation coefficient was calculated to determine the aspects that significantly affect the dependent variable. The statistical test design for analyzing the variables is shown in Figure 1.

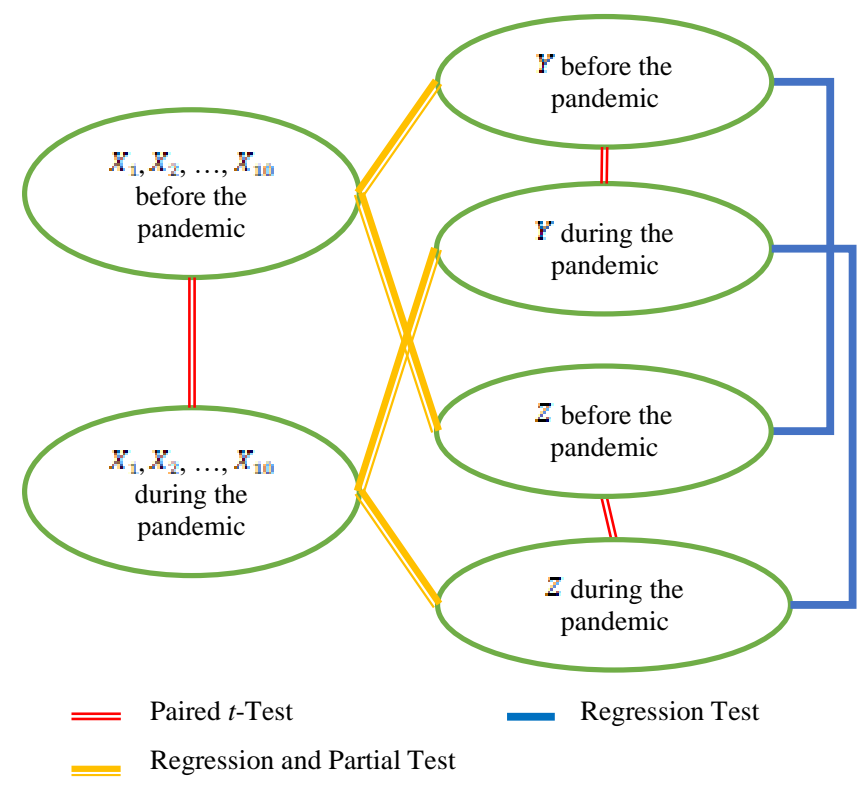

Fig 1. Statistical Test Design Between Variables

\section{RESULT AND DISCUSSION}

Data as many as 226 survey results were collected from thirteen universities from seventeen diverse faculties. $46 \%$ of students who filled out the survey were female, and 54\% were male. Only $6.6 \%$ of them were students as well as workers. $46.5 \%$ of students undergo online learning from where they live, $46.5 \%$ are rural, $36.3 \%$ are urban, and $7.5 \%$ are mountainous. The rest are in the lowlands and the coast.

There are so many types of social media that students use to communicate, but the majority, $49.6 \%$, actively use Instagram, and $14.6 \%$ use Facebook. While the platforms that are often used in online learning are $49.6 \%$, google meet, $11.5 \%$ Whatsapp, $8.4 \%$ Google class, and $10.6 \%$ Zoom. Other data collected will be analyzed by paired $t$ tests, regression tests, and partial tests.

We review student GPA and motivation before and during the pandemic. The average student GPA before the pandemic was 3.47 , and after the pandemic was 3.43 . Meanwhile, the student's motivation before the pandemic was dominated by the answer " thriving " (63.3\%), which changed to the answer " surviving" (45.6\%). The graph of student motivation before and after the pandemic can be shown in Figure 2.

Paired sample $t$-test was performed on observable variables before and during the pandemic. The results concluded that there were significant changes in various aspects observed, except for the involvement of students in social activities, and family engagement. Even though there was an average increase in family engagement, the increase was not significant. Furthermore, from these results, it was also concluded that the average GPA of students actually decreased after the pandemic took place, but it was not significant. Therefore, this decreased GPA cannot be 
concluded as a result of a pandemic. Table I shows the results of paired $t$-test using alpha $=0.05$.

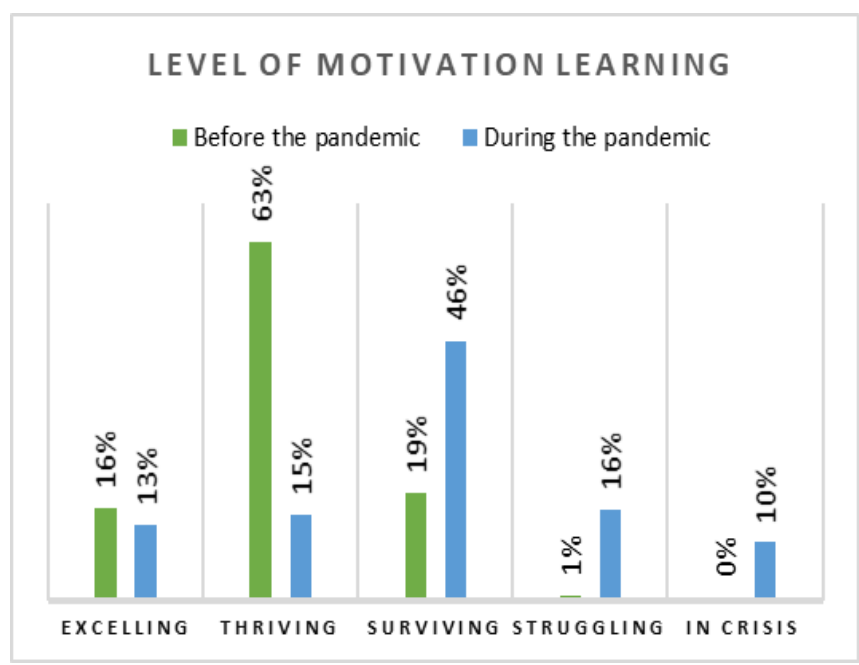

Fig. 2 The level of student motivation before and during the pandemic

TABLE I

PAIRED SAMPLE $T$-TEST RESUlT

\begin{tabular}{lcc}
\hline \multicolumn{1}{c}{ Variables } & $\boldsymbol{t}$-Stat. & Sig \\
\hline Student involvement in student activity units $\left(\boldsymbol{X}_{1}\right)$ & $-3,204$ & 0,001 \\
\hline Student involvement in social activities $\left(\boldsymbol{X}_{2}\right)$ & $-0,001$ & 0,410 \\
\hline Student involvement in religious activities $\left(\boldsymbol{X}_{\mathrm{g}}\right)$ & $-4,326$ & 0,001 \\
\hline Interaction with college friends $\left(\boldsymbol{X}_{4}\right)$ & $-12,571$ & 0,001 \\
\hline Interaction with lecturers $\left(\boldsymbol{X}_{5}\right)$ & $-7,937$ & 0,001 \\
\hline Family engagement $\left(\boldsymbol{X}_{6}\right)$ & 0,403 & 0,343 \\
\hline Family economic condition $\left(\boldsymbol{X}_{7}\right)$ & $-18,544$ & 0,001 \\
\hline Health condition $\left(\boldsymbol{X}_{\mathrm{g}}\right)$ & $-6,483$ & 0,001 \\
\hline Activities using social media $\left(\boldsymbol{X}_{9}\right)$ & 3,763 & 0,001 \\
\hline Time spend reading $\left(\boldsymbol{X}_{10}\right)$ & $-3,260$ & 0,001 \\
\hline GPA $(Y)$ & 0,984 & 0,163 \\
\hline Learning motivation $(\boldsymbol{Z})$ & $-12,543$ & 0,001 \\
\hline
\end{tabular}

Aspects that significant changes in decreasing way were student involvement in student activity units, student involvement in religious activities, interaction with college friends, interaction with lecturers, economic conditions, health conditions, time spend reading, and learning motivation. The only thing that has seen a significant increase after the pandemic is intensity is the use of social media. The three aspects most affected by this pandemic are the economic aspect, interaction with college friends, and motivation learning with $t$-statistic values of -18,544, 12,571, and $-12,543$. Figure 3 shows the quality of the student's economy before and during the pandemic.

Linear regression test was performed on all variables, either individually (simple linear regression) or together (multiple linear regression). The result of the simple regression test on GPA and motivation variables shown in Table II. We can conclude that before the pandemic, the GPA value was significantly influenced by learning motivation. However, an interesting result after the pandemic, in such a contrast, GPA was not significantly affected by learning motivation. This fact is also supported by the absence of significant changes in student GPA, although there is a huge decrease in student motivation, as shown from the previous t-test. This can be used as material for further discussion and research on why student GPAs are not significantly affected by motivation after the pandemic. Research by Valverde-Berrocoso et al. (2020) states that a significant positive effect between lockdown and student performance occurs because students can change learning strategies, increasing their learning efficiency. However, other factors can also be analyzed, for example, whether there is a tendency for teachers to provide lower standards GPA during the pandemic.

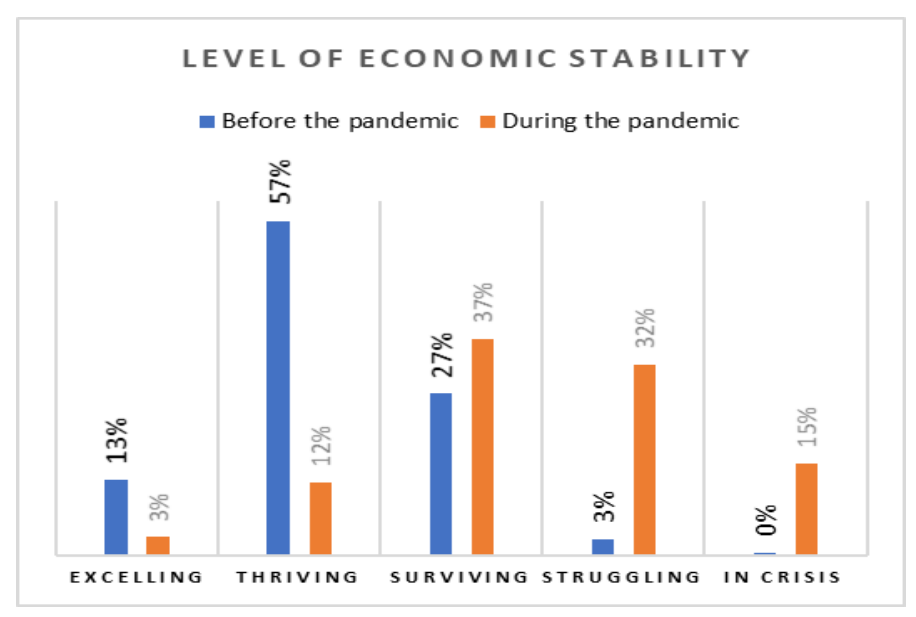

Fig. 3 Economic conditions of student families before and during the pandemic

TABLE II

REGRESSION TEST BETWEEN GPA AND LEARNING MOTIVATION

\begin{tabular}{ccc}
\hline Term & $\boldsymbol{F}$-stat & Sig. \\
\hline Before the pandemic & 10,930 & 0,001 \\
\hline During the pandemic & 0,022 & 0,879 \\
\hline
\end{tabular}

Furthermore, multiple linear regression tests were carried out on other observed aspects. The results of the regression test are shown in Table III. The regression test results show that the GPA value is not significantly affected jointly by the observed factors both before and during the pandemic. However, after the partial correlation test was carried out, it turned out that there was one factor that influenced the GPA before the pandemic: family engagement. The significant factors that affect the GPA during the pandemic are family involvement and student involvement in religious activities.

In multiple regression tests for the motivational aspect, the results obtained are significantly influenced by the factors observed before and during the pandemic. The factors that significantly influence individually before the pandemic are economic conditions and the allocation time of reading books. Meanwhile, after the pandemic, the 
factors that influenced motivation were more students' involvement in social activities $\left(X_{2}\right)$, interaction with lecturers $\left(X_{5}\right)$, health conditions $\left(X_{8}\right)$, and time spend reading $\left(X_{10}\right)$.

TABLE III

REGRESSION TEST USING GPA AND MOTIVATION AS DEPENDENT VARIABLE

\begin{tabular}{|c|c|c|c|c|}
\hline $\begin{array}{c}\text { Dependent } \\
\text { variable }\end{array}$ & $\begin{array}{c}\text { Independent } \\
\text { variable }\end{array}$ & Term & $F$-stat & Sig \\
\hline \multirow[t]{2}{*}{ GPA (Y) } & \multirow{2}{*}{ 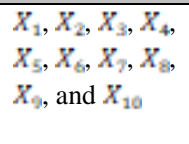 } & $\begin{array}{l}\text { Before the } \\
\text { pandemic }\end{array}$ & 1,714 & 0,078 \\
\hline & & $\begin{array}{l}\text { During the } \\
\text { pandemic }\end{array}$ & 1,858 & 0,052 \\
\hline \multirow[t]{2}{*}{$\begin{array}{l}\text { Motivation } \\
(\mathrm{Z})\end{array}$} & \multirow{2}{*}{ 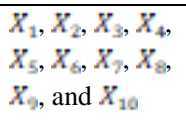 } & $\begin{array}{l}\text { Before the } \\
\text { pandemic }\end{array}$ & 4,358 & 0,001 \\
\hline & & $\begin{array}{l}\text { During the } \\
\text { pandemic }\end{array}$ & 6,724 & 0,001 \\
\hline
\end{tabular}

TABLE IV

REGRESSION TEST ON SIGNIFICANT INDEPENDENT VARIABLES BASED-ON PARTIAL $T$-TEST

\begin{tabular}{lllllll}
\hline & \multirow{2}{*}{$\begin{array}{l}\text { Significant } \\
\text { variables }\end{array}$} & \multicolumn{2}{c}{ Partial $\boldsymbol{t}$-test } & \multicolumn{3}{c}{ Regression test } \\
\cline { 3 - 7 } GPA & & $\boldsymbol{t}$-stat. & Sig. & Coeff. & $\boldsymbol{F}$-stat. & Sig. \\
\hline Before & $\begin{array}{l}\text { Family } \\
\text { engagement }\end{array}$ & $-2,453$ & 0,014 & $-0,056$ & 4,97 & 0,026 \\
\hline During & $\begin{array}{l}\text { Student } \\
\text { involvement } \\
\text { in religious } \\
\text { activities }\end{array}$ & $-2,508$ & 0,012 & $-0,123$ & 8,036 & 0,001 \\
& $\begin{array}{l}\text { Family } \\
\text { engagement }\end{array}$ & $-2,841$ & 0,004 & $-0,137$ & & \\
\hline Motivation & & & & & & \\
\hline Before & $\begin{array}{l}\text { Family } \\
\text { economic } \\
\text { condition }\end{array}$ & 3,162 & 0,001 & 0,255 & 13,729 & 0,001 \\
\cline { 2 - 7 } & $\begin{array}{l}\text { Time spend } \\
\text { reading }\end{array}$ & 2,546 & 0,011 & 0,080 & & \\
\hline During & $\begin{array}{l}\text { Interaction } \\
\text { with lecturers }\end{array}$ & 4,066 & 0,001 & 0,108 & 15,522 & 0,001 \\
\cline { 2 - 7 } & $\begin{array}{l}\text { Time spend } \\
\text { reading }\end{array}$ & 3,184 & 0,001 & 0,333 & & \\
\hline $\begin{array}{l}\text { Family } \\
\text { economic } \\
\text { condition }\end{array}$ & 2,397 & 0,017 & 0,181 & & \\
\hline $\begin{array}{l}\text { Student } \\
\text { involvement } \\
\text { in social } \\
\text { activities }\end{array}$ & 2,133 & 0,034 & 0.190 & & \\
\hline & & & & & & \\
\hline
\end{tabular}

Furthermore, based on the partial test, a regression test was conducted on the aspects that significantly affect the GPA and learning motivation, as shown in Table VI. From the regression results, the model for motivation during the pandemic with intercept 0,4232 is shown in equation (6).

$$
Z=0,423+0,108 X_{2}+0,333 X_{5}+0,181 X_{8}+0,190 X_{10}(6)
$$

Recommendations based-on the model can be given to foster student learning motivation related to student involvement in social activities, which positively increases student learning motivation. Therefore, students can be directed to participate more actively in social activities that may be used as learning programs. This can be related to research by Abidah et al. (2020) which discusses online learning from the point of view of "Merdeka Belajar", and research Mishra et al. (2020) on the management of change in the education system so that it can overcome distractions and lead to normal academic procedures.

The next interesting thing is about the effect of reading as an aspect that significantly affects motivation. After the pandemic, students' reading habits have decreased significantly. The analyzed data also shows that the interest in reading among students is still shallow. It was noted that after the pandemic occurred, there were still as many as $23.5 \%$ of students who did not take the time to read books or other reference sources. This is certainly a serious problem that needs to be considered by all educators and stakeholders on how to foster interest in reading to support educational success.

\section{IV.CONCLUSSION}

This study is a quantitative study that examines indirect aspects that affect student motivation and academic achievement, represented by GPA scores, in higher education before and during the pandemic. The paired t-test showed significant changes in learning motivation, economic conditions, health conditions, student interactions with friends and lecturers, student involvement in student activity units and religious activities, activity in social media, and time spend reading. Aspects that affect GPA and learning motivation were analyzed using linear regression. The results show that the GPA value before the pandemic was influenced by learning motivation. However, after the pandemic, the GPA value was not significantly affected by learning motivation. The multiple linear regression test followed by a partial test showed that the GPA value before the pandemic was influenced by family engagement. Meanwhile, significant factors that affect the GPA are family engagement and student involvement in religious activities during the pandemic. In motivation, the results obtained were that learning motivation before the pandemic is influenced by economic conditions and the time spend reading. Meanwhile, after the pandemic, the factors that influence motivation are student involvement in social activities, interaction with lecturers, health conditions, and the time spend reading.

\section{REFERENCES}

Abidah, A., Hidaayatullaah, H. N., Simamora, R. M., Fehabutar, D., \& Mutakinati, L. (2020). The Impact of Covid-19 to Indonesian Education and Its Relation to the Philosophy of “ Merdeka Belajar.” 1(1), 38-49. Retrieved from https://sciejournal.com/index.php/SiPoSE/article/view/9/5

Ariani, D. wahyu. (2017). Do social relationship affects motivation? Advances in Management \& Applied Economics, 7(3), 1792-7552. Retrieved from https://www.researchgate.net/publication/318946151

Arlinwibowo, J., Retnawati, H., Kartowagiran, B., \& 
Kassymova, G. K. (2020). Distance Learning Policy In Indonesia for Facing Pandemic Covid-19: School Reaction and Lesson Plans. Journal of Theoretical and Applied Information Technology, 98(14). Retrieved from http://www.jatit.org/volumes/Vol98No14/13Vol98No 14.pdf

Balan, S., Katenga, J. E., \& Simon, A. (2019). Reading Habits and their Influence on Academic Achievement among Students at Asia Pacific International University. Abstract Proceedings International Scholars Conference, 7(1), 1469-1495. https://doi.org/10.35974/isc.v7i1.928

Edraki, M., Parvizi, N., Montaseri, S., \& Pourahmad, S. (2016). The Relationship Between Academic Motivation and General Health and the Effective Factors on This Relationship in Female High School Students. International Journal of School Health, 4(1), 1-9. https://doi.org/10.17795/intjsh-39712

Febrianto, P. T., Mas'udah, S., \& Megasari, L. A. (2020). Implementation of Online Learning during the Covid19 Pandemic on Madura Island , Indonesia. International Journal of Learning, Teaching and Educational Research, 19(8), 233-254. https://doi.org/https://doi.org/10.26803/ijlter.19.8.13

Gonzalez, T., Rubia, M. A. De, Hincz, K. P., Subirats, L., Fort, S., \& Sacha, G. M. (2020). Influence of COVID19 confinement on students 'performance in higher education. PLOS ONE, 15(10). https://doi.org/10.1371/journal.pone.0239490

Hendri, H., Mulyani, S. R., \& Salim, E. (2020). The Effect of Achievement Motivation, How To Learn, and the Economic Conditions of Parents on Gpa of Computer Science Student. Education, Sustainability And Society, 3(1), 20-26. https://doi.org/10.26480/ess.01.2020.20.26

Jawad, Y. A. L. A., \& Shalash, B. (2020). The Impact of ELearning Strategy on Students, Academic Achievement Case The Impact of E-Learning Strategy on Students Academic Achievement Case Study: Al- Quds Open University. International Journal of Higher Education,
https://doi.org/10.5430/ijhe.v9n6p44

Mahdy, M. A. A. (2020). The Impact of COVID-19 Pandemic on the Academic Performance of Veterinary Medical Students. Frontiers in Veterinary Science, 7(October). https://doi.org/10.3389/fvets.2020.594261

Mishra, L., Gupta, T., \& Shree, A. (2020). International Journal of Educational Research Open Online teaching-learning in higher education during lockdown period of COVID-19 pandemic. International Journal of Educational Research Open, 1(August), 100012. https://doi.org/10.1016/j.ijedro.2020.100012

Murphy, M. P. A. (2020). COVID-19 and emergency eLearning: Consequences of the securitization of higher education for post-pandemic pedagogy COVID-19 and emergency eLearning : Consequences.
Contemporary Security Policy, 41(3), 492-505. https://doi.org/10.1080/13523260.2020.1761749

Muslimin, A. I., \& Harintama, F. (2020). Online Learning during Pandemic : Students' Motivation, Challenges , and Alternatives. Loquen:English Studies Journal, 60-68.

https://doi.org/http://dx.doi.org/10.32678/loquen.v13i 02

Nurhopipah, A. (2019). Visualisasi Pengaruh Antar Variabel TPB Melalui Graf Berdasarkan Regresi Bertahap. CITISEE, 243-248. Retrieved from https://citisee.amikompurwokerto.ac.id/assets/proceed ings/paper/46_Ade_Nurhopipah_CITISEE_2019.pdf

Panisoara, I. O., Lazar, I., Panisoara, G., \& Chirca, R. (2020). Motivation and Continuance Intention towards Online Instruction among Teachers during the COVID-19 Pandemic: The Mediating E ff ect of Burnout and Technostress Technostress. International Journal of Environmental Research and Public Health, 17. https://doi.org/10.3390/ijerph17218002

Patricia Aguilera-Hermida, A. (2020). College students' use and acceptance of emergency online learning due to COVID-19. International Journal of Educational Research Open. https://doi.org/10.1016/j.ijedro.2020.100011

Rahardjo, A., \& Supratmi Pertiwi. (2020). Learning Motivation and Students 'Achievement in Learning English: A Case Study at Secondary School Students in the Covid-19 Pandemic Situation. 1(2), 56-64.

Suryaman, M., Cahyono, Y., Muliansyah, D., Bustani, O., Suryani, P., Fahlevi, M., ... Harimurti, S. M. (2020). COVID-19 pandemic and home online learning system: Does it affect the quality of pharmacy school learning? Systematic Reviews in Pharmacy, 11(8), 524-530. https://doi.org/10.31838/srp.2020.8.74

Tedja, J. N. (2020). The Implementation of Distance Learning Policy During the Covid-19 Pandemic. Indonesian Journal of Digital Society, 1(2), 18-28. Retrieved from http://journal.unas.ac.id/sosiologiijds/article/view/903/pdf 2

Valverde-Berrocoso, J., María del Carmen Garrido-Arroyo, Burgos-Videla, C., \& Morales-Cevallos, M. B. (2020). Trends in Educational Research about e-Learning : A Systematic Literature Review ( 2009 - 2018 ). Sustainability, 12. https://doi.org/10.3390/su12125153

Zhu, X., \& Liu, J. (2020). Education in and After Covid-19: Immediate Responses and Long-Term Visions. Postdigital Science and Education (2020), 2, 695-699. https://doi.org/https://doi.org/10.1007/s42438-02000126-3 